\title{
Assessment of Undiscovered Hydrocarbon Resources of the Western Oregon and Washington Province
}

Using a geology-based assessment methodology, the U.S. Geological Survey estimated mean volumes of 2.2 trillion cubic feet (TCF) of undiscovered natural gas and 15 million barrels of oil (MMBO) in the Western Oregon and Washington Province. More than 67 percent, or $1.5 \mathrm{TCF}$, of the undiscovered natural gas is continuous gas estimated to be coalbed gas in Tertiary coals in western Oregon and Washington.

\section{Introduction}

The U.S. Geological Survey (USGS) recently completed an assessment of the undiscovered, technically recoverable oil and gas resources of the Western Oregon and Washington Province (fig. 1). The province includes all of Oregon and Washington north of the Klamath Mountains and west of the crest of the Cascade Range. It extends offshore to the 3-mi limit of State waters on the west and to the International Boundary in the Straits of Juan de Fuca and Canada on the north. The province measures about $450 \mathrm{mi}$ north-south and 50 to $160 \mathrm{mi}$ east-west, encompassing more than $51,000 \mathrm{mi}^{2}$ (fig. 1).

The assessment of the Western Oregon and Washington Province is geology based and used the total petroleum system (TPS) concept. The geologic elements of a TPS include hydrocarbon source rocks (source rock maturation and hydrocarbon generation and migration), reservoir rocks (quality and distribution), and traps for hydrocarbon accumulation. Using these geologic criteria, the USGS assessment team defined two conventional and one unconventional (continuous) total petroleum systems with one assessment unit (AU) in each TPS: (1) the Cretaceous-Tertiary Composite TPS and the Western Oregon and Washington Conventional Gas AU, (2) the Tertiary Marine TPS and the Tertiary Marine Gas AU, and (3) the Tertiary Coalbed Gas TPS and the Eocene Coalbed Gas AU, in which a cell-based methodology was used.

The province (fig. 1) occupies a complex geologic setting along the northwest continental margin of North America. Some $5,000 \mathrm{ft}$ to more than $23,000 \mathrm{ft}$ of Paleogene volcanic rocks, marine mudstone and arkosic and lithic sandstone, and nonmarine arkosic and lithic sandstone, mudstone, carbonaceous shale, and coal are present in western Oregon and Washington; these rocks include potentially mature source rocks and reservoir rocks.

Before 1979, the only oil and gas production was in the Washington part of the province, near Grays Harbor, from 1957 to 1961 (fig. 1) where about 12,000 barrels of oil and associated gas were produced. Currently, the only hydrocarbon production within the province is from the Mist gas field in northwestern Oregon

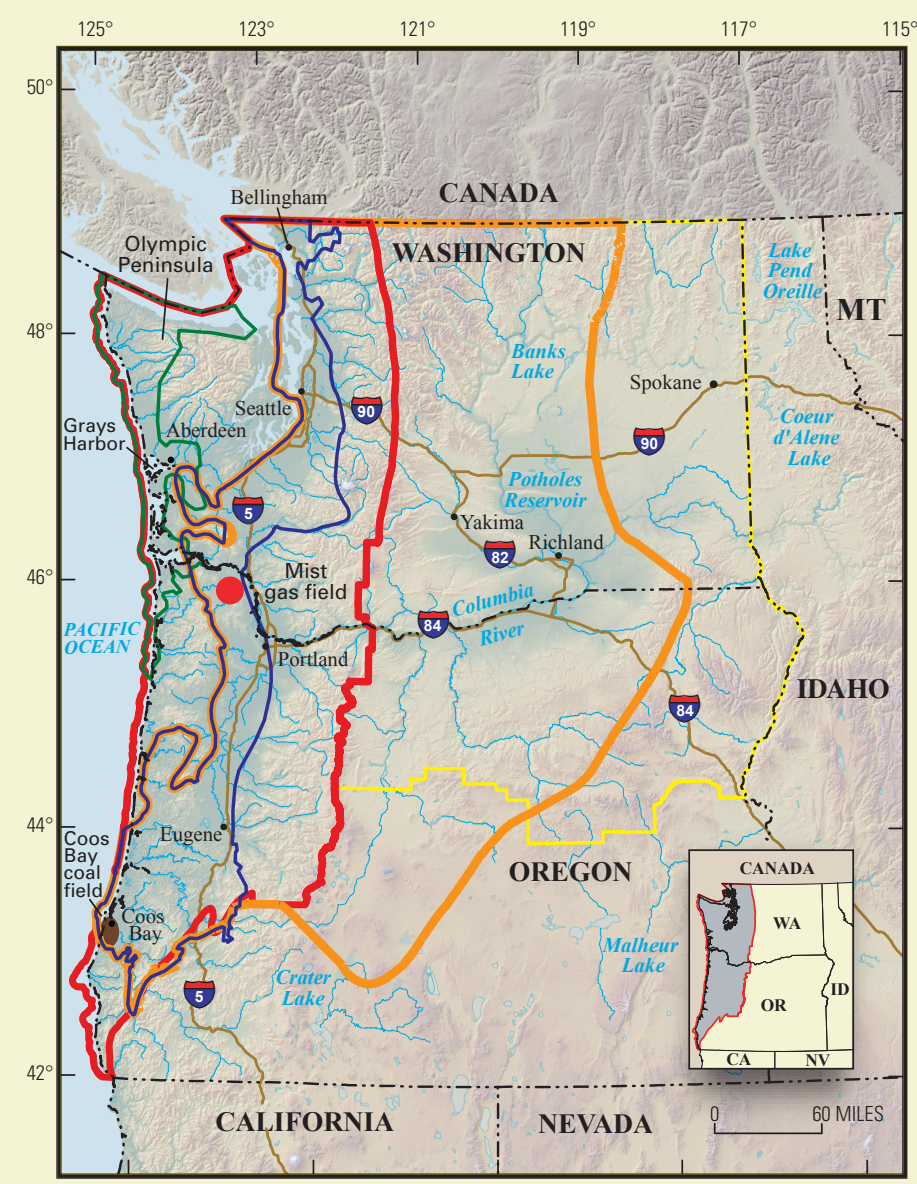

Figure 1. Western Oregon and Washington Province located in western Oregon and Washington; boundary is shown in red. CretaceousTertiary Total Petroleum System (TPS) is shown in orange. Tertiary Coalbed Gas TPS is shown in dark blue. Tertiary Marine TPS shown in dark green. Eastern Oregon and Washington Province boundary is shown in yellow (Brownfield, 2008). Location of the Coos Bay coal field shown as a solid brown oval and the Mist gas field shown as a red circle.

(fig. 1) that was discovered in May 1979. The Mist field has produced about 65 billion cubic feet of gas (BCFG) from upper Eocene Cowlitz Formation reservoirs through 2008.

\section{Resource Summary}

The USGS assessed both undiscovered technically recoverable conventional oil and gas and continuous (unconventional) coalbed gas in the Western Oregon and Washington Province (table 1), resulting in an estimated total mean of 2.2 trillion cubic feet of gas (TCFG) and a mean of 15 million barrels of oil (MMBO). More than 67 percent of the total mean gas (1.5 TCFG) is contained within the hypothetical Eocene Coalbed Gas $\mathrm{AU}$, 
Table 1. Western Oregon and Washington Province assessment results.

[MMBO, million barrels of oil; BCFG, billion cubic feet of gas; MMBNGL, million barrels of natural gas liquids. Results shown are fully risked estimates. For gas accumulations, all liquids are included as the NGL (natural gas liquids). Undiscovered gas resources are the sum of non-associated and associated gas. F95 represents a 95 percent chance of at least the amount tabulated; other fractiles are defined similarly. Fractiles are additive under assumption of perfect correlation. TPS, total petroleum system; AU, assessment unit; CBG, coabed gas. Gray shade indicates not applicable.]

\begin{tabular}{|c|c|c|c|c|c|c|c|c|c|c|c|c|c|}
\hline \multirow{3}{*}{$\begin{array}{l}\text { Total Petroleum System (TPS) } \\
\text { and Assessment Unit (AU) }\end{array}$} & \multirow{3}{*}{$\begin{array}{l}\text { Field } \\
\text { Type }\end{array}$} & \multicolumn{12}{|c|}{ Total Undiscovered Resources } \\
\hline & & \multicolumn{4}{|c|}{ Oil (MMBO) } & \multicolumn{4}{|c|}{ Gas (BCFG) } & \multicolumn{4}{|c|}{ NGL (MMBNGL) } \\
\hline & & F95 & F50 & F5 & Mean & F95 & F50 & F5 & Mean & F95 & $\mathrm{F} 50$ & $\mathrm{F5}$ & Mean \\
\hline \multicolumn{14}{|c|}{ Cretaceous-Tertiary Composite TPS } \\
\hline \multirow{2}{*}{$\begin{array}{l}\text { Western Oregon-Washington } \\
\text { Conventional Gas AU }\end{array}$} & Oil & 0 & 0 & 0 & 0 & 0 & 0 & 0 & 0 & 0 & 0 & 0 & 0 \\
\hline & Gas & & & & & 79 & 403 & 1,000 & 454 & 0 & 1 & 2 & 1 \\
\hline \multicolumn{14}{|l|}{ Tertiary Marine TPS } \\
\hline \multirow{2}{*}{ Tertiary Marine Gas AU } & Oil & 2 & 9 & 45 & 15 & 3 & 14 & 70 & 22 & 0 & 1 & 4 & 1 \\
\hline & Gas & & & & & 34 & 195 & 646 & 249 & 1 & 5 & 17 & 6 \\
\hline Total Conventional Resources & & 2 & 9 & 45 & 15 & 116 & 612 & 1,716 & 725 & 1 & 7 & 23 & 8 \\
\hline \multicolumn{14}{|l|}{ Tertiary Coalbed Gas TPS } \\
\hline Eocene Coalbed Gas AU & CBG & 0 & 0 & 0 & 0 & 565 & 1,307 & 3,024 & 1,489 & 0 & 0 & 0 & 0 \\
\hline Total Continous Resources & & 0 & 0 & 0 & 0 & 565 & 1,307 & 3,024 & 1,489 & 0 & 0 & 0 & 0 \\
\hline $\begin{array}{l}\text { Total Undiscovered } \\
\text { Oil and Gas Resources }\end{array}$ & & 2 & 9 & 45 & 15 & 681 & 1,919 & 4,740 & 2,214 & 1 & 7 & 23 & 8 \\
\hline
\end{tabular}

which encompasses an area of more than 11 million acres. In this continuous AU the Eocene coals, such as the coal-bearing Eocene Coaledo Formation (fig. 2) serve as both the source rock and reservoir. Within the Western Oregon-Washington Conventional Gas AU the USGS estimated a mean volume of 454 BCFG. An estimated mean volume of $15 \mathrm{MMBO}$ of conventional oil and 725 BCFG is in the Tertiary Marine AU, which contains Paleogene turbidite rocks (fig. 3). In this assessment unit there are numerous gas and oil seeps, and the potential source rocks are marine shales and the reservoir rocks are arkosic and lithic turbidite sandstones.

\section{For Additional Information}

Supporting geologic studies of Total Petroleum Systems and Assessment Units, and reports on the methodology used in the Western Oregon and Washington Province assessment are in progress. Assessment results are available at the USGS Central Energy Team website, http://energy.cr.usgs.gov/oilgas/noga/.

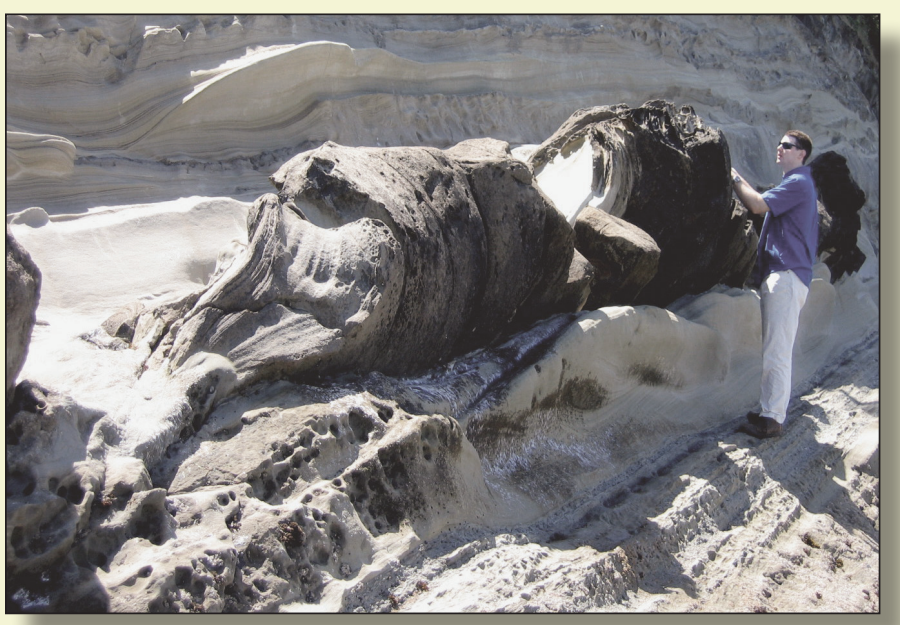

Figure 2. Outcrop of part of the deltaic lower member of the middle Eocene Coaledo Formation at Sunset Bay State Park, near Coos Bay, Oregon (fig. 1). Soft sediment deformation can be seen in the center of the photo. Strata are dipping eastward toward the trough of the South Slough syncline in the Coos Bay coal field (fig. 1).

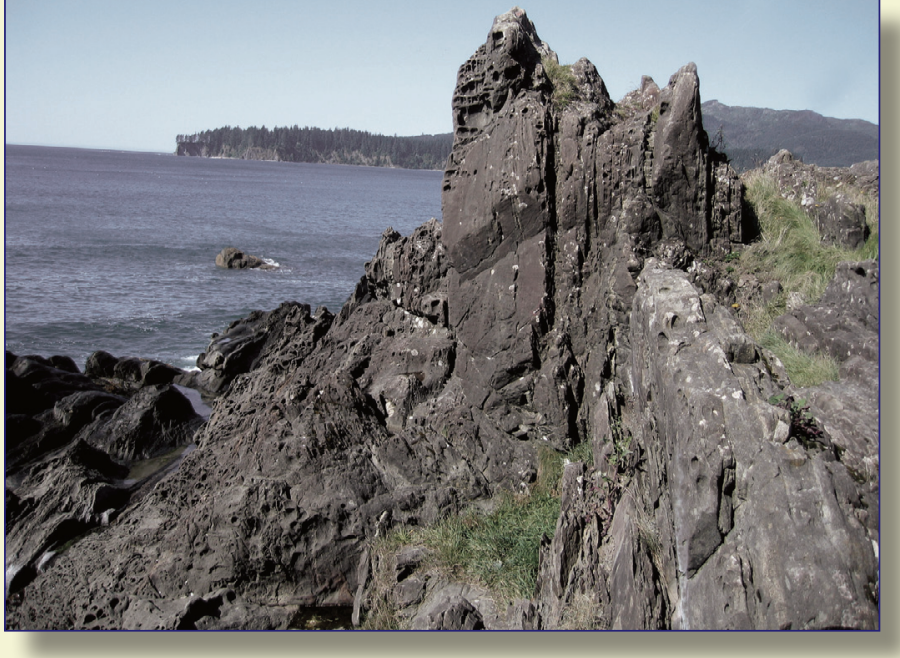

Figure 3. Upper Eocene turbidite sandstone rocks along the northwest shore of the Olympic Peninsula, northwestern Washington. Cape Flattery is in the distance. Turbidite units are potential reservoirs within the Tertiary Marine TPS and the Tertiary Marine Gas AU.

\section{Western Oregon and Washington Province Assessment Team:}

Michael E. Brownfield (mbrownfield@usgs.gov), Ronald R. Charpentier, Troy A. Cook, Timothy R. Klett, Richard M. Pollastro, and Christopher J. Schenk.

\section{References}

Brownfield, M.E., 2008, Chapter 2-Cretaceous-Tertiary composite total petroleum system and geologic assessment of undiscovered gas resources of the Eastern Oregon and Washington Province, in U.S. Geological Survey Eastern Oregon and Washington Assessment Team, Geologic assessment of undiscovered gas resources of the eastern Oregon and Washington province: U.S. Geological Survey Digital Data Series DDS-69-O, 43 p. 